\title{
ESP PRACTITIONERS' ROLE AND THEIR ETHNOGRAPHY: A CASE STUDY OF ESP PRACTITIONERS AT THE INDONESIAN TERTIARY LEVEL
}

\author{
Kun Aniroh Muhrofi-Gunadi \\ Diploma IV Tourism Program \\ Universitas Merdeka Malang \\ kun.aniroh@unmer.ac.id
}

First draft received: 28 April 2016

Final proof received: 26 August 2016

\begin{tabular}{|l} 
Abstract \\
This current research aims at revealing factual ESP practitioners' roles at the tertiary level of education \\
in Malang City, Indonesia. Data were collected through semi-structured interviews and a survey using \\
questionnaires involving 22 ESP practitioners selected randomly from several universities and colleges \\
in Malang. To collect data on the roles of ESP practitioners, the present study adopted two sources in \\
the questionnaires: First, the roles of ESP instructors as teachers, course designers, materials \\
providers, researchers, and evaluators as proposed by Dudley-Evans and St. John (1998), and \\
secondly as a practitioner who has intercultural competence and professional activity competence as \\
defined by Luka (2004) and ethnography (Wall, 2014). The findings showed that the majority (70\%) of \\
ESP practitioners realized their roles and some (30\%) claimed to learn more on mastering contents, \\
providing materials, conducting research on needs analysis, learning intercultural competence, and \\
realizing the needs to have experiences in industries or related work places of the students. Concerning \\
their ethnography, the majority of ESP practitioners did not have the opportunity to teach, to have \\
internship, and to work in industries. Only 2 (9.1\%) ESP practitioners studied the field of what students \\
learn. Future research on the collaboration between academics and practitioners is needed to make \\
ESP classrooms a 'real world'. \\
Keywords: ESP practitioners, role, tertiary level, ethnography, workplace \\
To cite this paper (in APA style): \\
Muhrofi-Gunadi, K. A. (2016). ESP practitioners' role and their ethnography: A case study of ESP \\
practitioners at the Indonesian tertiary level. International Journal of Education, $9(1), 1-9$. doi: \\
dx.doi.org/10.17509/ije.v9i1.3711
\end{tabular}

\section{INTRODUCTION}

The marginalizing of English for Specific Purposes (henceforth ESP) at the university level in the Indonesian context is obviously observable in the credit load of ESP courses. The course offers only 24 credits in the English Department and the nonEnglish Department, and 6-8 credits at the colleges. Studies on the implementation of teaching English atnon English departments conducted in Java and Sumatra as observed by Sulistyo (2008) revealed the undesirable sides of the teaching of English that are associated with the teaching of ESP. Another study by Sulistyo (2013) also revealed that college students' readiness in academic content area reading was low. It is argued that this empirical evidence is related among other things to the marginalizing of ESP at the university level.

With the growth of English as a lingua franca, where English is limited to being used as a means of not only general communication but also commerce, aviation, logistics, accounting, engineering, health, and tourism, the teaching condition of ESP described previously should not happen, as English will also be used in other sectors soon. This implies that ESP is supposed to get more attention in terms of optimizing ESP practitioners' role in the classrooms.

It might be not too far-fetching to state that for some decades English for specific purpose (ESP) has been marginalized in English language teaching (henceforth ELT), at the English Department and the non-English Department in Indonesia. This is due to the fact that the credit load of the ESP courses is only 2 to 4 credits (Academic Guidelines of Universitas Merdeka Malang, 2014) and in the English Department, ESP is an elective subject of 2 to 4 credits (The Catalog of English Literature Department of Universitas Negeri Malang, 2015). For ESP practitioners, this is not enough for developing the language skills and/or contents and implementing ESP competences (Luka, 2004). Another fact supporting the marginalization of ESP courses in Indonesia is that most ESP instructors are Englishfor-general-purpose (henceforth EGP) instructors with no adequate training in ESP, and only a few ESP instructors have an additional background of the subject she or he is teaching. This makes the ESP instructors not motivated, and this has the effect that ESP is considered unchallenging for the instructors and the students, resulting in the ineffectiveness of ESP instruction (Alwasilah, 2000). The fact is different for colleges of specific fields such as tourism, health, and engineering that offer more credits in English. However, in those colleges most of the English instructors are EGP-based with no adequate ESP training.

In line with the growth of English as a lingua franca in many parts of the world, including ASEAN Economic Community that specifies on engineering, architecture, nursing, doctor, dentistry, accounting, health, and tourism (Lubis, 2015), EGP is no longer sufficient to cater to the ever expanding communication needs. This trend challenges the 
practice of EGP instruction into more ESP ones. This implies that there is a compelling need to have a shift in the teaching orientation from EGP to ESP ones (Muhrofi-G, 2009). In other words, if English instructors have to teach EGP courses, they need to be sensitive to the issues and the development of English in the global market. Thus, this paper aims at analyzing how ESP practitioners position and act their roles in order to know and enhance their teaching quality. The process of working experiences to be ESP practitioners known as ethnography was also conducted.

\section{The Roles of ESP Practitioners}

EGP and ESP have been mentioned in literature, both for their theory and practice. Hutchinson and Waters (1987) stated that theoretically they are the same; however, there are a great deal of dissimilarities in their practice. Both EGP and ESP practitioners share the same knowledge of teaching language. However, in actual practice, ESP practitioners' activities cover among, other things, research, including needs analysis, becoming course developers, collaborators, and evaluators (DudleyEvans and St. John, 1998). Meanwhile, to some extent EGP instructors rarely practice these areas. ESP has special characteristics on content. Therefore, learning with subject specialists and learning about the students' major constitute an important element. The main issue of ESP teaching is making an effort to gain knowledge of language and the student's topic (Helsvig, 2012). Lowe (2010) argued that an ESP teacher has to teach reliable content and skills because learning them leads to the learning of language.

With reference to the role of ESP instructors, Dudley-Evans and St. John (1998) identified five key roles of ESP practitioners: As a teacher, course designer and materials provider, collaborator, researcher and evaluator. Meanwhile, Luka (2004) stated that the ESP competences needed by ESP practitioners consist of communicative competence, professional activity competence, and intercultural competence. Professional activity competence refers to professional competence in industries. Intercultural competence refers to viewpoints that contain curiosity, broad-mindedness, and acceptance (Luka, 2004). In this study, only the last two of Luka's (2004) ideas, professional activity competence and intercultural competence, are examined among ESP practitioners. Many research articles have discussed the role of ESP practitioners and professionalization through apprenticeship of practice (Sierocka, 2008; Ghanbari and Eslami, 2012; and Saadia, 2012). However, since ESP is specific, ESP practitioners have their own points of view regarding ESP teaching. They tend to conduct ESP teaching based on their work experiences and their own personal experiences and research findings. These views nevertheless enrich the role of ESP practitioners.

Another characteristic or even a critical feature of ESP is that its course should involve language specialists, especially when dealing with related terms and terminologies and contents. In the majority of cases, ESP teachers are not language specialists in the students' professional fields. That is why the primary issue in ESP teaching includes the struggle to master language and subject matter (Helsvig, 2012 and Lowe, 2010).

Based on the discussion of roles, it is obvious that an ESP practitioner conceptually plays multiple roles. In reality, an ESP expert needs to practice these conceptual roles as these are ideal for ESP instructions to be optimal. Considering this, therefore a study needs to be carried out to reveal the match between the ideal roles an ESP practitioner needs to play and the actual roles they can do. The purpose of the present study is to examine ESP teachers in terms of their practical roles as outlined in these aspects: A teacher, course designer and materials provider, collaborator, researcher and evaluator. In addition, the present study also examines their professional activity competence, intercultural competence, and the ethnography of ESP practitioners of how they learn to get closer to the workplace.

\section{Ethnography of ESP Practitioners}

Most of ESP practitioners graduated from English education department where there is not enough ESP credits or training (Academic Guidelines of Universitas Merdeka Malang, 2014), and they are used to being EGP instructors, or novice ESP practitioners. Therefore, there is a need to conduct a study of ethnography that is their work experiences. Ethnography is the study of past events related to indepth understanding of the group of people (Case, Todd, \& Kral, 2014). For instance, Wall (2014) conducted a study from 2008-2010 to investigate work experiences of nurses. Another study was about "natural habitat" and "on line habitat" of a group of people informing the way how they interact in their social communities (Hallet \& Barber, 2014). In addition, the study of the university students' culture and life was portrayed through ethnography for explaining the vital role and the switch of the tertiary education (Illoh and Tierney, 2013).

\section{How ESP Practitioners Reach the Career Path}

To know the career path of ESP practitioners is crucial because as what is pointed out by Ahmed (2014), ESP practitioners' role is more complicated and accountable than that of GE practitioners. What needs to be noted is that ESP practitioners are not subject specialists, but English teachers (Ahmed, 2014). A study by Alsolami (2014) pointed out that among EGP teachers who taught ESP, they had difficulties and scarcity on functional academic literacy and field of knowledge, training, materials and ESP libraries.

The 21st century is said to be the new world for ESP teaching. In China, ESP teachers have chances and problems in the sense that they must not only be aware of the teaching benefits of ESP but also their role to the ESP teaching development (Sun, 2007). In addition, Jigang (2012) mentioned that general literacy in basic English of university graduates is no longer enough, and to add with professional English abilities such as English for the firms, enterprises, joint ventures, is a great help for the students. It means that ESP practitioners have the expertise, and to increase experienced skillfulness, more attention needs to be directed toward the combination of competence which does not relate to each other, 
disciplinary knowledge, and professional practice (Bhatia, Anthony, and Noguchi, 2011)

\section{METHOD}

For the purpose of the present study, a survey design was employed. The target population of the present study was all ESP college instructors (henceforth respondents) in Malang City who taught English at the college level. Originally, 35 were identified as the target respondents. However, only 22 respondents $(63 \%)$ completed the questionnaire. So, the present survey involved these respondents who were selected randomly from 2 colleges and 3 universities in Malang, East Java, Indonesia. Those involved in the present study are 9 novice ESP practitioners, i.e. those who have less than 7 years teaching experiences, and 13 senior practitioners, i.e. those who have more than 7 years teaching experiences.

A set of questionnaires was developed based on the role concept of ESP practitioners to examine the respondents' roles. There are seven main roles of ESP practitioners that are elaborated in the questionnaire: The role as a teacher, course designer, researcher, collaborator, and an evaluator as conceptually proposed by Dudley-Evans and St. John (1997). In addition, two concepts, namely "intercultural competences, and professional competence in industries" as proposed by Luka $(2004$, p. 7$)$ or related workplace were considered in the questionnaire. These roles were further elaborated into their corresponding indicators, resulting in a total of 33 items: 13 in the role as a teacher, 4 in a course designer, 2 as a researcher, 3 as a collaborator, 3 as an evaluator, 2 as an intercultural competent practitioner, and 5 as a professional competent practitioner. The items in the questionnaires require the respondents to state their level of agreement on each of these seven factors from completely agree (CA) - 4 points - to completely disagree (CD) - 1 point. Concerning ESP practitioners' ethnography, a set of questionnaires was developed to examine ESP practitioners' experience closer to the workplace. There are 10 questions about how to get closer to the industry which were adapted from the study of Wall (2014) and Hallet and Barber (2014). The items in the questionnaire ask the respondents to state Yes or No.

Prior to the distribution, the questionnaire was validated by an expert and then tried out to examine the reliability of the questionnaire and the validity of each item. Based on the feedback from experts, some revisions on contents and wording were made. The tryout of the instrument involved 30 ESP teachers that were not included as the respondents of the present study. Inter-rater reliability was examined on the response of these five ESP teachers. The Alpha statistical computation was exerted to examine the reliability of the tryout data. The reliability of the questionnaires was .876. This means that the items in the questionnaire were very consistent in yielding the scores. Meanwhile, out of 33 items (100\%) that were generated as indicators in the questionnaire, 19 items $(58 \%)$ were valid at the level of significance of not only .05 but also .01 with coefficients of Pearson's correlation in the range of .434 to .822 . So, in terms of questionnaire reliability and item validity, the questionnaire was considered a good instrument with consistency and validity assurance to collect data needed.

The data collected were analyzed quantitatively based on the frequency of appearance that is then made into percentages. The next section presents the results of the analysis of the role of ESP practitioners seen from their role as a teacher, course designer and materials provider, collaborator, researcher and an evaluator. In each of these factors, several indicators are elaborated.

\section{FINDINGS AND DISCUSSION}

The result of the analysis on the data of teachers' role as a teacher is summarized in Table 1.

Table 1. Role as a teacher

\begin{tabular}{|c|c|c|c|c|c|c|c|c|}
\hline \multirow{2}{*}{ Role as a Teacher } & \multicolumn{2}{|c|}{ CD } & \multicolumn{2}{|c|}{$\mathrm{D}$} & \multicolumn{2}{|c|}{ A } & \multicolumn{2}{|c|}{$\mathrm{CA}$} \\
\hline & $f$ & $\%$ & $f$ & $\%$ & $f$ & $\%$ & $f$ & $\%$ \\
\hline Understanding the ESP content subject & - & - & 1 & 4.5 & 10 & 45.5 & 11 & 50 \\
\hline Understanding content subject based on the students' major & - & - & 1 & 4.5 & 10 & 45.5 & 11 & 50 \\
\hline Understanding the goals and objectives of ESP & - & - & 1 & 4.5 & 6 & 27.3 & 15 & 68.2 \\
\hline Collaborating with students in understanding content & 1 & 4.5 & 2 & 9.1 & 6 & 27.3 & 13 & 59.1 \\
\hline Collaborating with subject specialists & - & - & 5 & 22.7 & 10 & 45.5 & 7 & 31.8 \\
\hline Consulting with departments' local authorities on ESP programs & - & - & 1 & 4.5 & 9 & 40.9 & 12 & 54.5 \\
\hline Teaching listening & 1 & 4.5 & 3 & 13.6 & 10 & 45.5 & 8 & 36.4 \\
\hline Teaching speaking & - & - & 2 & 9.1 & 5 & 22.7 & 15 & 68.2 \\
\hline Teaching writing & 2 & 9.1 & 3 & 13.6 & 6 & 27.3 & 11 & 50 \\
\hline Teaching reading for content area comprehension & 1 & 4.5 & - & - & 4 & 18.2 & 17 & 77.3 \\
\hline Teaching the four skills based on the students' needs & 1 & 4.5 & - & - & 7 & 31.8 & 14 & 63.6 \\
\hline Listening to the input from the students on the content & & & 4 & 18.2 & 12 & 54.5 & 16 & 27.3 \\
\hline $\begin{array}{l}\text { Having a high interest on ESP and taking a risk in teaching } \\
\text { though not understanding the content }\end{array}$ & 6 & 27.3 & 6 & 27.3 & 7 & 31.8 & 3 & 13.6 \\
\hline
\end{tabular}

The result of the survey on the role of ESP practitioners as a teacher indicated that the ESP practitioners played their roles. In general, the respondents stated that they strongly agreed (44\%) and agreed $(40 \%)$ on their role as ESP teachers on the points of subject content, specific subject, goals and objectives, cooperation with the students and subject specialists, consultation with local authority department, teaching listening, speaking, reading and writing based on the students' needs, and listening to the students 'input. However, a few (16\%) disagreed on the point of the interest on ESP and did not want to take a risk to teach, as they did not know the content. The result of the analysis on the data of the teachers' role as a course designer and a materials provider is summarized in Table 2 . 
Table 2. Role as a course designer and a materials provider

\begin{tabular}{|c|c|c|c|c|c|c|c|c|}
\hline \multirow{2}{*}{ Role as a Course Designer and a Materials Provider } & \multicolumn{2}{|c|}{$\mathrm{CD}$} & \multicolumn{2}{|c|}{$\mathrm{D}$} & \multicolumn{2}{|c|}{ A } & \multicolumn{2}{|c|}{ CA } \\
\hline & $f$ & $\%$ & $f$ & $\%$ & $f$ & $\%$ & $f$ & $\%$ \\
\hline Using the existing materials & 2 & 9.1 & 2 & 9.1 & 15 & 68.2 & 3 & 13.6 \\
\hline Using the existing materials and add with other materials & 2 & 9.1 & - & & 9 & 40.9 & 11 & 50 \\
\hline Selecting the existing materials based on the students' needs & - & - & - & - & 10 & 45.5 & 12 & 54.5 \\
\hline Creating own materials & 3 & 13.6 & 2 & 9.1 & 13 & 59.1 & 4 & 18.2 \\
\hline
\end{tabular}

On the role of ESP practitioners as a course designer and materials provider, several of the teacher respondents (39\%) strongly agreed and most $(53 \%)$ agreed on using the available materials, adding the available materials with others, selecting the available ESP materials based on the students'

need, and making their own materials. Of those points, few $(8 \%)$ did not agree on making their own materials.

The result of the analysis on the data of the teachers' role as a researcher is summarized in Table 3.

Table 3: Role as a researcher

Role as a Course Designer and a Materials Provider Conducting needs analysis

Learning and doing job analysis to know the language functions to be used by the students

The next is the role of ESP practitioners as an ESP researcher. The results indicated that a few teacher respondents (14\%) strongly agreed and mostly (64\%) agreed on the points of needs analysis and job analysis to match language function, and
$23 \%$ disagreed on their role as researchers on needs analysis.

The result of the analysis on the data of the teachers' role as a collaborator is summarized in Table 4.

Table 4: Role as a collaborator

\begin{tabular}{llccccccc}
\multicolumn{1}{c}{ Role as a Collaborator } & \multicolumn{2}{c}{ CD } & \multicolumn{1}{c}{ D } & \multicolumn{1}{c}{ A } & \multicolumn{2}{c}{ CA } \\
\cline { 2 - 9 } & $\mathrm{f}$ & $\%$ & $\mathrm{f}$ & $\%$ & $\mathrm{f}$ & $\%$ & $\mathrm{f}$ & $\%$ \\
\hline $\begin{array}{l}\text { Learning the subject specialist syllabus together with } \\
\text { subject specialists }\end{array}$ & 1 & 4.5 & 6 & 27.3 & 12 & 54.5 & 3 & 13.6 \\
\hline $\begin{array}{l}\text { Learning the genre in ESP materials and discusses it with } \\
\text { subject specialists }\end{array}$ & - & - & 2 & 9.1 & 13 & 59.1 & 7 & 31.8 \\
\hline $\begin{array}{l}\text { Learn the syllabus, genre and materials to teach and I } \\
\text { discuss it with subject specialists }\end{array}$ & - & - & 5 & 22.7 & 14 & 63.6 & 3 & 13.6 \\
\hline
\end{tabular}

Concerning the role of ESP practitioners as collaborators, most of the teacher respondents (59\%) strongly agreed and a few (18\%) agreed on the points of the willingness to learn the content, the materials, and the genre in the syllabus of specific subjects with subject specialists. The rest (23\%) disagreed on those points.

The result of the analysis on the data on the teachers' role as an evaluator is summarized in Table 5.

Table 5: Role as an evaluator

\begin{tabular}{lrrrrrrrc}
\hline \multicolumn{1}{c}{ Role as an Evaluator } & \multicolumn{2}{c}{$\mathrm{CD}$} & \multicolumn{1}{c}{$\mathrm{D}$} & \multicolumn{3}{c}{$\mathrm{A}$} & \multicolumn{3}{c}{$\mathrm{CA}$} \\
\cline { 2 - 9 } & $\mathrm{f}$ & $\%$ & $\mathrm{f}$ & $\%$ & $\mathrm{f}$ & $\%$ & $\mathrm{f}$ & $\%$ \\
\hline Evaluating ESP course outlines and materials periodically & 3 & 13.6 & 3 & 13.6 & 11 & 50 & 5 & 22.7 \\
\hline Conducting achievement tests & 2 & 9.1 & - & - & 8 & 36.4 & 12 & 54.5 \\
\hline $\begin{array}{l}\text { Suggesting the students to take standardized test and } \\
\text { other tests based on their needs }\end{array}$ & 2 & 9.1 & 5 & 22.7 & 8 & 36.4 & 7 & 31.8 \\
\hline
\end{tabular}

ESP practitioners have the role of not only testing the students based on their needs and conducting an achievement test and a standardized test, but also evaluating instructional materials periodically as industries, related workplaces, and other crucial issues influence instructional materials development. On those points, a few $(21 \%)$ strongly agreed, mostly (67\%) agreed, a few other (10\%) disagreed, and some (2\%) strongly disagreed.
The last two roles of ESP practitioners are those of teachers who have intercultural competence and professional competence. There are two points of intercultural competence: the capability to have a good attitude towards those who have different cultural background and the willingness to learn other cultures.

The result of the analysis on the data of the teachers' role as an ESP practitioner who has intercultural competence is summarized in Table 6 .

Table 6: Role as an interculturally competent ESP practitioner

Role as an Interculturally Competent ESP Practitioner

Having the capability to have a good attitude to those who

\begin{tabular}{cccccccc}
\multicolumn{2}{c}{$\mathrm{CD}$} & \multicolumn{2}{c}{$\mathrm{D}$} & \multicolumn{2}{c}{$\mathrm{A}$} & \multicolumn{2}{c}{$\mathrm{CA}$} \\
\hline $\mathrm{f}$ & $\%$ & $\mathrm{f}$ & $\%$ & $\mathrm{f}$ & $\%$ & $\mathrm{f}$ & $\%$ \\
\hline- & - & - & - & 5 & 22.7 & 17 & 77.3 \\
& & & & & & & \\
\hline- & - & 1 & 4.5 & 6 & 27.3 & 15 & 68.2 \\
\hline
\end{tabular}


The result of the analysis on the data of the teachers as an ESP practitioner who has professional competence is summarized in Table 7.

Of those points, the respondents mostly (57\%) strongly agreed, several (34\%) agreed, and a few $(9 \%)$ disagreed. On professional competence which consists of knowledge on the industry based on the students' background, experience in the industry and related workplace, problem solver and negotiator, and the ability to communicate in English in the workplace, several $(29 \%)$ of the teacher respondents strongly agreed, mostly (59\%) agreed, some (10\%) disagreed, and a few (2\%) strongly disagreed. In general, the results of the overall data from the respondents are summarized in Figure 1.

Table 7: Role as ESP practitioner with professional competence

\begin{tabular}{|c|c|c|c|c|c|c|c|c|}
\hline \multirow{2}{*}{ Role as an ESP Practitioner Having Professional Competence } & \multicolumn{2}{|c|}{ CD } & \multicolumn{2}{|c|}{$\mathrm{D}$} & \multicolumn{2}{|c|}{ A } & \multicolumn{2}{|c|}{$\mathrm{CA}$} \\
\hline & $f$ & $\%$ & $f$ & $\%$ & $f$ & $\%$ & $f$ & $\%$ \\
\hline Understanding the industry based on the students' interest & 1 & 4.5 & 4 & 18.2 & 10 & 45.5 & 7 & 31.8 \\
\hline Having knowledge about and experiences in industries & 2 & 9.1 & 10 & 45.5 & 6 & 27.3 & 4 & 18.2 \\
\hline Being capable to be a problem solver in a team & 1 & 4.5 & 6 & 27.3 & 9 & 40.9 & 6 & 27.3 \\
\hline Communicating well in English & - & - & - & & 6 & 27.3 & 16 & 72.7 \\
\hline $\begin{array}{l}\text { Being capable to be a negotiator on the students' needs outside } \\
\text { the class }\end{array}$ & 1 & 4.5 & 1 & 4.5 & 13 & 59.1 & 7 & 31.8 \\
\hline
\end{tabular}

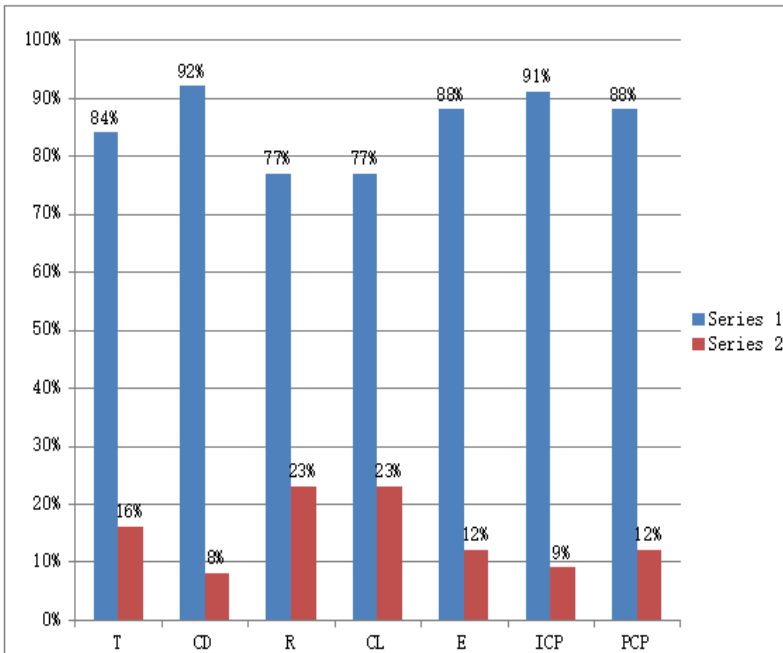

Figure 1: Summary of the Results of Analysis on ESP Teachers' Roles

Concerning ESP practitioners' ethnography of their work experience, all ESP practitioners 22 (100\%) learned from ESP books and the Internet. However, the percentages of those who learned from subject specialists were 20 (90.9\%), and 14 (63.6\%) from ESP colleagues.
Note:

T - Teacher

CL - Collaborator

Series 1 : Degree of a role claimed already played

CD - Course Designer

E - Evaluator

Series 2 : Degree of a role claimed not yet played

$\mathrm{R}$ - Researcher

ICP - Intercultural Competent Practitioner

PCP - Professional Competent Practitioner

Table 8. The ESP practitioners' ethnography of work experience

\begin{tabular}{|c|c|c|c|c|}
\hline \multirow{2}{*}{ ESP Practitioner's Work Experience } & \multicolumn{2}{|c|}{ Yes } & \multicolumn{2}{|c|}{ No } \\
\hline & $f$ & $\%$ & $f$ & $\%$ \\
\hline Learning from ESP books & 22 & 100.0 & 0 & 0.0 \\
\hline Learning from subject specialists & 20 & 90.9 & 2 & 9.1 \\
\hline Learning from ESP colleagues & 15 & 68.2 & 7 & 31.8 \\
\hline Learning from internet & 22 & 100 & 0 & 0.0 \\
\hline Learning from the students & 14 & 63.6 & 8 & 36.4 \\
\hline Teaching ESP at industries & 2 & 9.1 & 20 & 90.9 \\
\hline Studying at the same or similar department as the students & 2 & 9.1 & 20 & 90.9 \\
\hline Attending on-the job training/internship as the students do & 2 & 9.1 & 20 & 90.9 \\
\hline Understanding the workplace by working at industry & 1 & 4.6 & 21 & 95.4 \\
\hline Attending ESP training & 3 & 13.6 & 19 & 86.4 \\
\hline
\end{tabular}

\section{Discussion}

The teacher respondents are English teachers who teach EGP and ESP at universities and colleges. The findings show that the teacher respondents are aware of their roles of ESP practitioners as teachers, but
$16 \%$ disagreed on the point of the interest on ESP and did not want to take a risk to teach as they did not know and master the content. This means that the teacher respondents are willing to teach ESP, but when it comes to the content, they do not want to 
have the difficulty in integrating language and content. This finding reflects the idea that ESP and EGP share the same things in theory, but not in practice (Hucthinson and Waters, 1987). This can be seen in the findings that ESP practitioners were eager to train but did not want to make an effort to learn the materials (Helsvig, 2012). Lowe (2010) asserted that English teachers must teach the contents of specialist. This is certainly a challenge for EGP teachers when they teach ESP. Based on my casual observation at one of the colleges, novice ESP teachers tend to have difficulties in teaching. They claimed that subject content is not easy, and it takes time to learn. One of the examples is contents in tourism. In tourism, there are many subject contents or departments: Hotel department, tour and travel, and tourism destination management. In order to be easier in learning the contents of those departments, ESP teachers are suggested to choose what they are more interested in. They can also make their strong effort if the department assigns them to teach in a certain department.

With reference to teaching contents, my experience in supervising the English education students who developed materials for ESP indicates that the majority of the students got the difficulties in conceptualizing contents. They failed to understand what to be written in the topics, how to order the topics, and how to write the exercise and the assessment consistently based on the topics. As a consequence of this, it takes much time to guide them in writing about the topics. In addition, they also have difficulties in teaching confidently. There is also a tendency that they will go back to teach what they 'know'. That is, they focus more on teaching about language than content. To help them teach ESP confidently, I usually suggest them to read a lot of the topics, to discuss the content with the subject specialist, industries, learning community, and the stakeholders of the education institution.

Becoming a course developer is actually not only the duty of ESP teachers but also of EGPs. The problem of the ESP teaching learning process deals with the scarcity of customs and guidance, specific information, and inadequacy of useful materials (Sierocka, 2008). In this matter, the role of ESP practitioners as course designers and materials developers cannot be avoided. Similar findings with a higher percentage are also found in the role of ESP practitioner as a researcher. Some of the teacher respondents $(5 \%)$ disagreed on their role as researchers on needs analysis and few (3\%) strongly disagreed on their roles as practitioners who conducted job analysis to know the language functions. Bojović (n.d) stated that "ESP teachers must be familiar with investigation or experimentation. ESP teachers are provided with necessary knowledge and tools to deal with their own students' specializations" (p. 7). In conducting a needs analysis, designing a course, or writing teaching materials, teachers need to be competent in integrating the discovery of the research into their teaching practices. This is another role of ESP practitioners that is not fully carried out by ESP practitioners. Needs analysis is the major point in ESP, as one of the characteristics of ESP is accommodating the learners' needs. As Chambers (1980) asserted, "the term Target Situation Analysis and several other terms have also been introduced such as these Present Situation Analysis, Pedagogic Needs Analysis, Deficiency Analysis, Strategy Analysis or Learning Needs Analysis, Means Analysis, Register Analysis, Discourse Analysis, and Genre Analysis" (cited in Songhori, 2008, p. 3) With these many kinds of needs analysis, ESP practitioners can start conducting the analysis based on the students' needs, ESP practitioners' needs, and other needs which become the concerns of schools, departments, or institutions.

ESP practitioners also have the role as a collaborator. The result of the study shows that several (19\%) agreed and few (4\%) strongly disagreed on the role as a collaborator. This means the teacher respondents show their reluctance to collaborate with students or subject specialists or other related parties. The teacher respondents are not aware that teaching language solely in ESP without collaboration with subject specialists is still not complete. When talking about the aforementioned needs analysis, more stakeholders are actually collaborators of ESP practitioners. The more collaborative the ESP practitioners, the better information they have, and this will bridge them to be a professional ESP practitioner.

Regarding the role of an evaluator, a few (10\%) of the teacher respondents disagreed and a small number of them (2\%) strongly disagreed on performing these three points: achievement testing, standardized testing, and evaluating a course design periodically. Evaluating course designs is a must because science and technology that become the concern of ESP develop rapidly. The last year's course design might be different from this year's course design, as some new topics should be included and other topics might be dropped as they become irrelevant. In addition, Sierocka (2008) pointed out a lack of materials, a lack of specialist knowledge, tradition and guidelines are the obstacles and the demands. The main interest is that any concern related to the students' needs has to be discussed as the input for assessing the course design.

In the global world today where the human interaction is very high, ESP practitioners are demanded to have the role of practitioners who have intercultural competence. 9\% strongly disagreed with learning another country's culture. This means that the teacher respondents were not aware of the relation between ESP course and intercultural competence. One of the trends in ESP is targets that relate to ASIAN ESP, and in the future these mirror the advancement of internationalization, localization, business English, and field of proficient practice (Sangiamwibool, 2014). Internationalization and localization are unavoidable due to the international network among ASEAN countries; for instance, Asian and other network countries that accommodate the mobility of human resources of different education backgrounds, including vocational students. Internationalization refers to the global world, which means a global career, and sooner or later this will be experienced by vocational students (Muhrofi-Gunadi, 2014).

Intercultural competences refer to knowledge, skills and attitudes about a particular culture, including how to interact with the different and diverse 
cultures (UNESCO,2013). This means that with the development of English into a language that is widely used not only among the native speakers and nonnative speakers, but also nonnative speakers and nonnative speakers, the mutual learning of diverse cultures is considered crucial.

The aforementioned professional competent practitioner refers to competence in industry (Luka, 2004). A study on professional competence in professional careers in Taiwan shows that the analytical finding shows that task perspective was the dominant formulation for professional competence, and culinary professional competence was intermediary for useful knowledge presentation (Ko, 2012).

Nowadays, communicative competence without awareness of professional competence is not complete. As my experience in conducting a study on professional activities, these competences can be carried out in the campus laboratory as long as the laboratory represents the activities and facilities of industries. Another alternative is sending the ESP practitioners to related industries to widen the knowledge and practical things. This means cooperation with subject specialists, including those who are in the workplace, is essential. With the global world nowadays, verbal communication is unavoidable. That is, the ability to communicate in English has to be supported by the knowledge and skills of culture of the colleagues. Problem solving means always looking at the front based on the previous lesson learned so that better solution is gained. These skills need a lot of practice.

The last role of ESP practitioners in this study is a teacher with professional competence. A few $(20 \%)$ teacher respondents disagreed and few (9 \%) strongly disagreed with professional competence. The high percentage most likely lies in the absence of experiences in industries, being a problem solver, and understanding the background knowledge of the students. Competent capabilities refer to the capacity of professional competencies to deal with the ability to fulfill profession-related tasks with professional expertise. The research in tourism industry shows that experience competence and professional competence are the most crucial capabilities graduates must have (Zehrer and Mossenlechner, 2009. To support the experience in the study period, there is a period for college students to have a real practice in the industry, so this practice has to be conducted by the students and to be learned by ESP practitioners as a part of professionalism.

Writing experience in a certain field is one of the ethnographic studies. As Watson (2012) argued, the description and implementation of managerial ethnography is based on comprehensive research and writing skill and knowledge in the field. This means that from the point of view of how ESP practitioners achieve professionalism, there are many ways and steps to take.

\section{CONCLUSION}

There are 7 (seven) roles of ESP practitioners, namely as teachers, course developers, collaborators, evaluators (Dudley Evans and St John, 1998) and as ESP practitioners who have intercultural competence and professional competence (Luka,
2004). The following is the summary of the roles. First, on the role of ESP practitioners as a teacher, the majority of teacher respondents (84\%) agreed. Meanwhile, only a few (16\%) of teacher respondents did not agree on the points of taking a risk of teaching ESP, as they did not know the content. Next, on the role of ESP practitioners as course designers and materials providers, the majority (92\%) agreed; very few $(8 \%)$ did not agreed on the point of making their own instructional materials. Third, with the role of ESP practitioners as researchers, the majority $(77 \%)$ of the teacher respondents agreed and the rest $(23 \%)$ did not agree to make their own materials. The next is the role of ESP practitioners as collaborators. The majority $(77 \%)$ of the teacher respondents agreed and $23 \%$ disagreed on the willingness to learn the content, the materials, and the genre in the syllabus of specific subjects with subject specialists. Fifth, with the role of ESP practitioners as evaluators, the majority $(88 \%)$ of teacher respondents agreed and the rest of $12 \%$ disagreed to evaluate the materials periodically as a result of the development of industries, related workplace, and other crucial issues.

Finally, regarding the roles of ESP practitioners who have intercultural competence, the majority $(91 \%)$ of the teacher respondents agreed and very few $(9 \%)$ disagreed on knowledge about industries based on the students' background, experience on industries and related workplaces, problem solver and negotiator, and the ability to communicate in English in the workplace. Finally, with the roles of ESP practitioners who have professional competence which consists of knowledge about the industry based on the students' background, experience on industry and related workplace, problem solver and negotiator, and ability to communicate in English in the workplace, the majority ( $88 \%$ ) of teacher respondents agreed and $12 \%$ disagreed.

Ethnography can be said as the mirror of the career path of the respondents that will function to indicate how someone reaches a certain professional career. In the case of ESP practitioners who have many roles as observed in the present study (teacher, collaborator, researcher, materials developer (Dudley-Evans and St.John, 1998), and as a professional competent practitioner and a cultural practitioner (Luka, 2004), it might be possible that the respondents' role will develop into 'other roles'. It takes time for any ESP practitioner to implement the roles during the journey to be professional ESP practitioners. Each role has its own capacity in that an ESP practitioner has to learn a lot based on each role.

Based on the seven roles described above, the majority $(70 \%)$ of ESP practitioners realized their roles as ESP practitioners. Meanwhile, only a few $(30 \%)$ still did not realize their roles as ESP practitioners on the risk of continuously learning content, providing materials, conducting research on needs analysis, learning intercultural competence, and the needs to have experience in industry or related work place of the students. Therefore, updating knowledge on ESP by training, sending ESP practitioners to the related workplaces and industries, awareness of the development of science and technology and having passion in ESP teaching will 
be of a great help to make them professional ESP practitioners.

This is in line with Thomas' statement (2007) that scholarly analysis has been observed as being absent of applicability and effective operation of the the job in the present day employment and culture. Bhathia and Bremmer (2012) have added that in recent years we have been in growing inconsistency between study activities and proficient practice, to which the corporate world has been committed. In relation to English for Business Purposes (which is a root of ESP), Bhathia and Bremmer (2012, p. 16) put it this way "the synthesis of EBP with the subject discipline and the sub-discipline to encourage a new appropriation of disciplinary practice and approaches from the disciplinary cultures rather than from applied linguistics and language teaching."

What ESP practitioners have to do is to learn disciplinary practice and methodologies from those who have the expertise theoretically and practically, so that what to teach and what to do outside the classroom are not far from reality .

\section{Acknowledgments}

The author is grateful to novice and senior ESP practitioners at colleges and universities in Malang, East Java, Indonesia, who participated in this study.

\section{REFERENCES}

Academic Guidelines of Universitas Merdeka Malang. (2014). Malang: Universitas Merdeka Malang.

Ahmed, M.K. (2014). The ESP teacher: Issues, tasks and challenges. English for Specific Purposes World, 42(15) 1682-325, available from www.esp-world.info.

Alsolami, E. (2014). Barriers to teaching English for Specific Purpose among EGP teachers in the ELI. English for Specific Purpose World, 42(15), 1-23.

Alwasilah, C. (2000). Politik bahasa dan pendidikan (The politics of language and education), Second Edition. Bandung: Rosdakarya.

Bhatia, V, Anthony, L \& Noguchi, J. (2011). ESP in the 21 st century : ESP theory and application today. Retrieved from http://www.laurenceanthony.net/research/20110 830_0902_jacet_national_pres/jacet50_bhatia_ anthony noguchi.pdf

Bhatia, V. \& Bremmer, S. (2012). English for business communication, Language Teaching, 45(4), 410-445, DOI: 10.1017/S0261444812000171. Retrieved from https:www.researchgate.net/publication/259424 969

Bojović, M. (n.d). Teaching foreign language for specific purposes: teacher development. Retrieved from www.pef.uni-lj.si/atee/978961.../487-493.pdf 30/5/2015

Catalog of English Literature Department of Universitas Negeri Malang.(2007). Malang: Universitas Negeri Malang.

Case, A.D., Todd, N.R. \& Kral, M.J. (2014). Ethnography in community psychology. American Journal of Community Psychology, 54(1-2), 60-71.

Chambers , F. (1980). A re-evaluation on needs analysis in ESP. ESP Journal 1(1), 25-33.
Dudley-Evans, T., \& St.John, J.M. (1998). Developments in English for specific purposes. Cambridge: Cambridge University Press.

Ghanbari, B. \& Eslami, A. (2012). ESP Practitioner Professionalization through apprenticeship of practice: the case of two Iranian ESP practitioners. English Language Teaching, 2(5). Retrieved from http://www.ccsenet.org/journal/index.php/elt/artic le/view/14568

Hallet, R. \& Barber, K. (2014). Ethnographic research in cyber era. Journal of Contemporary Ethnography, 3(43), 306-330.

Helsvig, J. (2012). ESP-Challenges for Learners and Teachers in Regard to Subject-Specific Approach. Retrieved from https://ojs.kauko.It/index.php/ssktpd/article/view/ 99/96.

Hutchinson, T. \& Waters, A. (1986). English for Specific Purpose. A learning centered approach. Cambridge: Cambridge University Press.

Hwa, Ko, (2012). A study on relations among effective learning professional competence and learning performance in culinary field. Journal of Hospitality, Leisure, Sport and Tourism Education, 11(1), 12-20.

Illoh, C \& Tierney, W. (2013). Using ethnography to understand twenty-first century college life. Journal of Human Affairs, 24(1), 20-39.

Jigang, C. (2012) A study on needs analysis based ESP program at the tertiary level. Foreign Language Education, 5, 47-50.

Lowe, I. (2010). ESP teachers MUST teach specialist content. Retrieved from www.scientificlanguage.com/esp/content.pdf.

Lubis, U. (2015). 5 hal yang perlu disepakati soal masyarakat ekonomi ASEAN (5 things to be agreed upon concerning the ASEAN economic community). Retrieved from http://www.rappler.com/world/regions/asiapacific/indonesia/89311-5-masyarakat-ekonomiasean-2015.

Luka, I. (2004). Development of students' English for special purposes competence in tourism studies at tertiary level. Retrieved from: http://www.espworld.info/Articles_25/Ineta_Luka_ESP_World.p df.

Muhrofi-G, K.A. (2009). From English as a general school subject on to English as a Specific Subject: The needs to shift in the teaching orientation. TEFLIN Journal, 20(2). n.p.

Muhrofi-G, K.A. (2014). Mempersiapkan mahasiswa menuju kesuksesan global: Dari kecakapan wirausaha,penguasaan bahasa dan kepekaan budaya (Preparing students for global success: From entrepreneurship expertise, language masteri, and cultural awareness). Prosiding Seminar Nasional Bisnis dan Manajemen, 52-4.

Saadia, H.B. (2012). The Role of the ESP teachers : The case of ESP teachers at Algerian University. Retrieved from http://bu.univouargla.dz/master/pdf/bensaci_hali ma saadia.pdf?idmemoire $=249$

Sangiamwibool, A. (2014). Recent trends in ASIAN ESP. Retrieved from http://artikel.ubl.ac.id/index.php/icel/article/view/ 244 
Sierocka, H. (2008). The role of ESP teachers. Business English, 5(8), n.p. Retrieved from http://www.jezykangielski.org/theroleoftheesptea cher.pdf

Songhori, M. H. (2008). Introduction to needs analysis. English for Specific Purposes World, 4, 1-25.

Sulistyo, G.H.(2008). Pengembangan tes kemampuan memahami teks akademik berbahasa Inggris (Developing tests of English academic text comprehension skills) [Unpublished Dissertation]. Universitas Negeri Jakarta.

Sulistyo, G.H. (2013). Assessing non-English department students' mastery of academic content area reading. Jurnal Ilmu Pendidikan, 19(1), 37-49.

Sun, H. (2007).Reflections and Suggestions on the Development of ESP Teaching in China, Journal of Cambridge Studies, 2(1),36-42. Retrieved from

https://www.repository.cam.ac.uk/bitstream/han dle/1810/255630.

Thomas, G. (2007). How can we make our research more relevant? Bridging the gap between workplace changes and business communication research. Journal of Business Communication, 44(3), 283-289.

UNESCO. (2013). Intercultural Competences: Conceptual and Operational Framework Retrieved from http://unesdoc.unesco.org/images/0021/002197/ 219768e.pdf).

Wall, S. (2014). Focused Ethnography: A methodological adaptation for social research in emerging Contexts. Qualitative Social Research 16(1). Retrieved from http://www.qualitativeresearch.net/index.php/fqs/article/view/2182/372 8

Watson, T. (2012). Making organisational ethnography. Journal of Organizational Ethnography, 1, 15-22.

Wo, K. (2012).The relationship among professional competence, job satisfaction and career confidence for chefs in Taiwan. International Journal of Hospitality Management, 31(3), 1004 1011.

Zehrer, A \& Mossenlehner, C.( 2009). Key competencies of tourism graduates: The employers' point of view. Journal of Teaching in Travel and Tourism, 9, 266-287. DOI: 10.1080/15313220003445215. Retrieved from http://www.tandfonline/com/loi/wtt.20. 